\title{
Digital Technologies as the Basis for Optimizing Socioeconomic Development of Territories
}

\author{
N.Yu. Vlasova, E.S. Kulikova, O.A. Durandina \\ Ural State University of Economics, Yekaterinburg, Russia \\ *Corresponding author. Email: e.s.kulikova@mail.ru
}

\begin{abstract}
The relevance of the research topic is due to the need to improve the process of developing and implementing programs for the socioeconomic development of the regions in the Russian Federation. We should start by stating that the federal policy in relation to the regions was built in previous years on a platform for equalizing the socioeconomic development of the regions. Recently, much has been done to study the state and to justify the need to equalize the levels of socioeconomic development of the constituent entities of the Russian Federation. And it is worth noting that this is quite justified, because the alignment of the levels of socioeconomic development of the constituent entities of the Russian Federation is an important direction in ensuring domestic political stability in the country. However, the results of the current policy of leveling the development levels of the constituent entities of the Russian Federation are not always characterized by success in moving along this path. First of all, the reason is that the alignment of the socioeconomic development of the regions is possible only on the basis of accelerated growth in living standards in the most depressed regions of the country, which must be carefully monitored and controlled. But nevertheless, this scheme is still unsatisfactory in reality and, as a result, it does not lead to a weakening of differences in the development level of the constituent entities in the Russian Federation. The growing asymmetry in the socioeconomic development of the constituent entities of the Russian Federation is noted by many authors; economic resources and human resources are used to ensure uniformity of this process. However, practice shows that only digital technologies will allow in time to track and to adjust the socioeconomic strategy of territories in different parts of the Russian Federation and to ensure the uniformity of processes. This question is presented in our study, in the course of which empirical methods, analytical and statistical methods have been applied. In the work, such methods of cognition as analysis and synthesis, a system analysis of the processes of social development, methods of structural and functional analysis, comparison and generalization have been used. The information base of the study are regulatory sources (laws of the Russian Federation, acts of the executive and legislative branches of all levels), information on targeted programs.
\end{abstract}

Keywords: socioeconomic development, digital technologies, municipal unit, development strategy, system

\section{INTRODUCTION}

The processes of socioeconomic development have been launched throughout the Russian Federation, but this development is uneven, and part of the territories shows an absolute failure.

First of all, it should be noted the socioeconomic differences between the constituent entities of the Russian Federation in the following positions:

- in terms of output;

- by retail trade turnover per capita;

- by tax and non-tax revenues of the consolidated budgets of the constituent entities of the Russian Federation per capita;

- by the ratio of cash income per capita and the cost of living;

- by registered unemployment rate.
The current regional policy of the Russian Federation is aimed at improving the well-being of citizens and it is carried out by measures to stimulate or to contain various social processes, depending on which of them are considered useful for society and which are undesirable. Moreover, the main goal is to maintain and to establish social justice, as well as to solve purely economic regional problems through the market.

It should be noted that with the growth of population incomes in the process of economic development of Russia, the gap between the income level of the rich and the poor has grown. The choice of living wage values does not mean a real decrease in the poverty indicator, but an unjustified underestimation of this indicator by the Government of the Russian Federation, which is expressed, among other things, in the lag of its growth from the dynamics of average income growth.

Among the problems, it is worth highlighting the natural population decline, which can be offset by migration 
growth. But the scale of Russia's natural decline is so great that its full compensation through immigration seems unrealistic.

Thus, improving the process of developing and implementing programs for the socioeconomic development of the regions is of particular relevance, which predetermined the choice of the topic of the study.

\section{MATERIAL AND METHODS}

In the context of globalization of world economic processes and international political, economic relations, Russia is moving to a new state policy to ensure the country's sustainable development in the future and it is impossible to ensure this process without digital technologies.

Russia has goals and objectives, the decisive role in achieving which belongs to the regions, which, in turn, are built in the new regional policy as cultural and socioeconomic entities based on common social and economic life outside administrative borders.

It should be noted that most of the regions have prepared strategies for socioeconomic development, while the rest is in the process of development. Many strategies cover a period of 8 to 12 years, but some of them are designed for a longer period - up to 20-25 years. It becomes possible to control these processes, track the appropriateness of resource allocation only in the process of implementing digital control, that is, the mandatory presence of digital technology as a management and control tool at the present stage.

Thus, the development of a strategy for the socioeconomic development of regions in the new conditions of transformation of the Russian economy is the main tool for state regulation of socioeconomic processes at the regional level, which necessitates the subsequent development of theoretical aspects and methodological foundations of regional planning, as well as their adaptation to modern conditions and tasks of socioeconomic development. Analyzing the main approaches and views of foreign and domestic authors on strategic management and planning through digitization, it makes it possible to build a specific system of concepts for strategic management of regional digital development.

Thus, the strategic management of the socioeconomic development of the region is the purposeful activity of state authorities to ensure sustainable socioeconomic development and the successful functioning of the region for a longer period in accordance with the adopted doctrine and concept of long-term socioeconomic development of the country.

\section{RESULTS AND DISCUSSION}

Strategic regional planning is a system of state regulation with the help of strategic planning for the long-term socioeconomic development of the region, which consists in determining strategic goals and priorities, ways, means of achieving them, and forming the foundations of a mechanism for their implementation. In accordance with the Fundamentals of Strategic Planning in the Russian Federation, which were approved by Decree of the President of the Russian Federation dated May 12, 2009, strategic planning is carried out by developing concepts, doctrines, strategies, and programs - plans for sustainable development of the Russian Federation, taking into account the tasks of ensuring national security.

In this case, a key element of the strategic regional planning system is a strategy for the socioeconomic development of the region.

It is worth noting that the strategy of socioeconomic development of the region is a conceptual document of regional strategic planning, which reflects the main activities, goals, and means of the regional policy to ensure sustainable socioeconomic development of the region for the long term.

The main stages of strategic planning for regional development should be highlighted:

- design stage of a strategy for the socioeconomic development of the region;

- stage of the region development strategy implementation. So, when forming the strategy for the socioeconomic development of the region, the initial stage emphasizes the justification for the need for a program-targeted approach and determining the goals of ensuring the sustainable development of the region. At the same time, how much the set goals and objectives will be achieved depends on the effectiveness of the mechanism for implementing the strategic plan.

In order to achieve the set goals, to implement the strategic plan successfully, and to put into action all program measures, purposeful governing state influence on the socioeconomic development of the region should be used. Therefore, public administration is a lever that sets in motion and coordinates all the processes and stages of strategic development among themselves.

Thus, the mechanism for implementing the development strategy is an integral part of the strategic management system for the development of the region, which implies that the public administration system should be adapted and brought into line with the strategic course and focused on the implementation of strategic goals and objectives.

However, theoretical issues in the field of creating a mechanism for implementing a development strategy at the regional level are currently not worked out enough due to the relatively recent spread of strategic management in the practice of managing the Russian economy.

Analyzing research in this area, we can distinguish the opinion of O.V. Kolomiychenko and V.Ye. Rohchin in their interpretation of the concept of "a mechanism for implementing the development strategy of the region", namely, in their opinion, the mechanism for implementing the development strategy of the region is defined as a set of principles, forms, and methods, as well as tools for managerial influence on the socioeconomic development of the region in order to implement the strategic choice [2]. However, in this definition, the subject of the implementation of the set of elements of managerial 
influence is not clearly indicated. The subject of the implementation of the socioeconomic development strategy of the region is the government, which carries out a targeted integrated impact on all business entities located in the region in order to ensure the implementation of strategic directions of its development. Given this fact, the mechanism for implementing the development strategy of the region is a set of principles, functions, methods, as well as tools of managerial influence on the process of socioeconomic development of the region, which are used by regional authorities to achieve strategic goals and to ensure regional development priorities.

Moreover, the main function of this mechanism is to ensure the transfer of the region economy to a qualitatively new socioeconomic state, which is characterized by the achievement of strategic goals and objectives of its development, which allows us to formulate the structure and main elements of the mechanism for implementing the development strategy.

The creation of an efficiently functioning mechanism is based on the main methodological principles that are characteristic for the formation of a strategic management system, which should include consistency, continuity, efficiency, social partnership, publicity and openness, adaptability and focus, and priority.

It is important to note that the policy of the region should create such mechanisms and tools that, through regulation of economic and social relations, could ensure the maintenance of an active environment for the sustainable development of the region.

Among the subjects of economic relations in the region, economic entities and individuals, as well as public authorities, should be distinguished. However, not all existing economic relations are directly established by the governing authority, but nevertheless, they are subject to its influence in some way.

Regional policy is multidimensional due to the fact that the management of the region covers various areas of society. First of all, it should be noted that there is a sign of the uniqueness of a sub-federal socioeconomic policy for the Russian regions because of their special natural, economic, and social conditions. It depends on the following components of a single sub-federal socioeconomic policy, namely: social, investment, financial and credit, foreign economic, industrial, tax, budget, etc. Thus, the balance of these components is a prerequisite for the comprehensive socioeconomic development of the region.

It is worth noting that the regional socioeconomic system, which has signs of integrity and stability of internal relations, as well as the ability to reproduce, is always subject to influence from the relevant sub-federal authorities that conduct regional policy.

So, the socioeconomic development of the region, as a rule, is expressed in the reproduction of the aggregate social product, services, information, population, as well as socioeconomic relations. Given that any development has a focus, which is determined by the goal or the system of goals, the development of the region should go in the direction of social progress, manifested in an increase in social wealth, i.e. the whole set of objective and subjective conditions of life support and human life, the harmonious development of man himself on this basis, as well as nature, society, production, and the State as a whole.

Consequently, the socioeconomic development of the regions can be defined as an objective process that occurs not only in the regions themselves, but also in the country as a whole under the influence of historical, geographical, resource, and demographic factors. While the development of regions is a subjective process that occurs under the influence of managerial measures, as well as governing bodies of municipal units.

The state policy in the field of strategic management should be carried out on a partnership basis, as well as be open to interaction with market participants and the public.

In this case, it is necessary to highlight public-private partnerships as one of the main strategic directions and conditions for the implementation of the strategy of socioeconomic development, in which trust and productive interaction between business and government is established. Using the mechanisms of public-private partnerships, the region has the opportunity to stimulate the flow of private investment in the economy for the implementation of strategic projects, as well as to contribute to the development of innovative technologies in the region.

The effective functioning of the implementation mechanism is determined by the availability of the appropriate legal and digital resource support for the implementation of the regional development strategy.

Organizational and legal support, as a rule, consists in the adoption of regulatory legal acts that should regulate the implementation of the strategy, as well as in the formation and maintenance of all components of the organizational structure for the development strategy implementation.

Resource support is a combination of existing and potential opportunities and resources of the region, which are directly used in the process of the socioeconomic development strategy of the region. This may include financial, informational, and human resources.

Management functions should be considered together with the structural components of the mechanism for implementing the strategy. In order to successfully achieve the strategic goals in modern business conditions, the following functions are applied to the strategic management of the region:

- planning;

- execution (implementation);

- control;

- monitoring.

It should be noted that in the context of constant changes in the external environment and periodic reorientation of goals, the planning process is always continuous. The control is based on monitoring and evaluation of programs and helps to create a feedback between the planning process and the results of managerial decisions on its implementation.

It is also noteworthy the composition of the structure of methods of managerial influence on the process of implementing the strategy, namely, program-targeted, economic, organizational-administrative, and socialpsychological methods. 
The most widely used in Russia and the regions was the program-targeted digital method, the introduction of which into the practice of regional management allows for systematic and coordinated activities of government bodies in achieving strategic goals and objectives, as well as concentration of resources in the more priority areas of development, integration and targeting of events to solve certain problems and problems of the socioeconomic development of the region.

It should be noted that the implementation of these methods in modern business conditions provides for a shift in emphasis mainly towards digital economic and socialpsychological, but organizational-management (administrative) methods should not be excluded. Among their advantages, one should single out a targeted and prompt solution to more acute contradictions in the socioeconomic field, as well as ensuring priority in the development strategy implementation of the region.

Thus, the formation of an effective system of strategic management of the region development in order to achieve its strategic goals and regional development priorities will be facilitated by the integrated digital content of the mechanism for implementing the strategy with the listed functional structural elements.

Among the problems of effective planning by the socioeconomic development of the region, the presence of gaps in the legal framework should be noted. First of all, the successful implementation of the strategy is hindered by the different level and quality of legal regulation of the fulfillment of the functions for forecasting and programming, as well as operational budgeting. As a rule, effective and high-quality regulation allows for the implementation of the budget process, as a result of which, operational budgeting prevails over long-term strategic one. The different quality of the legal technique of acts should also be noted among the problems. For example, the Budget Code is one of the first laws of direct action, which contains certain procedures for the activities of the public authorities. At the same time, the law on forecasting is a declarative law that contains mainly reference norms and the implementation of which depends on the Government, in particular, sanctions are not enforced.

The next important problem is the lack of legal regulation of issues for joint exercise of powers by the executive bodies of state administration, which causes the problem of non-fulfillment or "unilateral" execution of the state administration functions.

Analyzing the functions and powers of public authorities, we can conclude that there is no digital system-organized activity for planning and implementing socioeconomic policies at the level of regional executive bodies. As a significant drawback in their work, it should be noted, among other things, that there are no legislatively fixed digital indicators of activity efficiency and responsibility for their failure to achieve, which would allow specifically and objectively considering and evaluating the performance of each specific function of the executive authority.

Support to the regions, which is carried out at the expense of higher budgets, should be considered as an auxiliary mechanism of regional policy, while it should be accompanied by conditions that will stimulate the outstripping economic development of lagging regions. It should be emphasized here that the preservation of digital conditions for the dynamic development of the leading regions in terms of economic development is the main task. However, the use of various instruments of influence on the socioeconomic development of regions, namely, federal target programs, the Investment Fund, special economic zones, and venture financing, is carried out without appropriate digital coordination in the absence of clear priorities for the regional economy, which requires the necessary direction of the actions of these instruments to support development. These problems impede the implementation of an effective regional policy and discourage regional government authorities to increase their own revenues and, accordingly, the development of the region, and also hinder the solution of the problem of reducing interregional differences in the level of citizens' provision with budget services and the progressive socioeconomic development of the region. Thus, there is an increase in an imbalance in the socioeconomic situation of the regions, which is offset by an increase in intergovernmental transfers in the field of existing regional development management. Digital technologies are rescuing the situation. At the same time, such measures can aggravate the severity of the problem in the absence of a single federal system of goals for the development of the State and stimulation of the economic potential realization of the region. In this regard, during the crisis, many aspects of managing the socioeconomic development of the regions need adjustment, and there is a need for a new approach to managing and developing methods for regulating the socioeconomic development processes of the regions.

It is noteworthy that the need to manage the socioeconomic development of the region is caused by general shortcomings in the functioning of the market economy, its focus on obtaining an economic effect, and ignoring the problems of social justice. In turn, the general shortcomings in the functioning of a market economy are due to market failures, as well as its inability to take into account the social needs of the population.

Management of the socioeconomic development of the region is an important element of the State regulation of the economy. It should be noted that there are many digital approaches to determining the management of the region's economy, but the unifying factor is the consideration of the management process as a targeted influence of the management entity, which are the public authorities, on the management object, which is represented by the socioeconomic development, using various principles, methods, and functions.

Some researchers consider the management of the socioeconomic development of the region to be a creation, legislative consolidation, as well as support and a guarantee for the digital practical implementation of certain conditions for highly efficient management of various types of human activities [3].

At the same time, some domestic and foreign authors define the management of the socioeconomic development of the region as the process of developing all kinds of digital 
powers between territories of different ranks (republic, region, city, district) determine the range of functions and powers of one or another level of power, which through digital technologies can in time track, regulate, and optimize the desired processes. The criterion for the distribution of the socioeconomic management functions between different levels of the territorial system is the degree of localization of using the results of the functions performed under the influence of digital systems. Not the scale and quantitative parameters of the socioeconomic development, but the totality of the functions carried out should become a distinctive feature of the administrativeterritorial digital platforms of various ranks. This approach to solving this problem allows us to specify the responsibility for solving socioeconomic problems at each level of regional governance.

\section{REFERENCES}

[1] Abalkin L.I. Cel' Ekonomicheskoj Strategii, www.inst-econ.org.rn

[2] Al'tudov YU.K., Ketova N.P., Ovchinnikov V.N. Mekhanizm Postkrizisnogo Razvitiya Ekonomiki Regionov Rossii. Rostov n/D.: Izd-vo Rost, unta, 2002. $320 \mathrm{~s}$.

[3] Babkov A.G. Indikativnoe Upravlenie Vosproizvodstvennym Razvitiem Regional'nyh Ekonomicheskih Sistem. Nal'chik: Poligrafservis i T, 2004. -228 s.

[4] Bezrukov V., Novosel'skij V. Ocenka Investicionnoj Deyatel'nosti v Federal'nyh Okrugah // Investicii v Rossii, № 12 (95), 2002 g. - S. 17-20.

[5] Bocharnikov I.V. Osnovnye Napravleniya Protivodejstviya Separatizmu v Rossijskoj Federacii // Vlast', 2008, No. 11, s. 19

[6] Belokrylova O.S., Gil'yano A.A. Investicionnyj Klimat Regiona: Kriterii Racional'nosti i Institucional'naya Struktura. Rostov n/D.: Izd-vo Rost, un-ta, 2003. - $144 \mathrm{~s}$.

[7] Blinov A. Metody Privlecheniya Investicionnyh Resursov na Municipal'nom Urovne // Investicii v Rossii, No. 10 (93) 2002 g.

[8] Blinov A., Orlova I. Upravlenie Investicionnoj Privlekatel'nost'yu Regiona // Investicii v Rossii, No. 12 (95), 2002 g. - S. 3-6.

[9] Butov V.I., Ignatov V.G., Ketova N.P. Osnovy Regional'noj Ekonomiki. Uchebnoe Posobie. Moskva. Rostov n/D: 2000. 448 s. 